УДК $378: 615$

\title{
СУЧАСНІ ПІДХОДИ ДО ОНОВЛЕННЯ СТАНДАРТІВ ВИЩОЇ ФАРМАЦЕВТИЧНОЇ ОСВІТИ
}

\author{
В. П. Черних, І. С. Гриценко, С. В. Огарь, Л. М. Віннік \\ Наиіональний фармачевтичний університет \\ NEW APPROACHES TO UPDATE STANDARDS HIGHER \\ PHARMACEUTICAL EDUCATION \\ V. P. Chernykh, I. S. Hrytsenko, S. V. Ohar, L. M. Vinnik \\ National University of Pharmacy
}

\begin{abstract}
У статті проаналізовано досвід розробки освітніх стандартів вищої фармацевтичної освіти. Вказано на важливості його розвитку і удосконалення.
\end{abstract}

The article analyzed the experience of development of educational standards of higher pharmaceutical education. The importance of its development and improvement is considered.

Вступ. У сучасних умовах актуальним завданням $€$ створення нових стандартів професійної фармацевтичної освіти, розробка нових навчальних планів i програм, що враховують міжнародні освітні системи і стандарти. Необхідно розширювати і поглиблювати міжнародне співробітництво в галузі фармацевтичної освіти, створювати і творчо впроваджувати прогресивні ідеї зарубіжного і вітчизняного досвіду, інтеграції національної системи вищої освіти в міжнародний професійно-освітній простір.

Основна частина. Приєднавшись до Болонського процесу, перед українською освітянською громадою відкриваються нові орієнтири:

- соціально-економічні й політичні зрушення детермінують необхідність вчасної модернізації системи вищої освіти, зумовлюють необхідність глибинного реформування національної освітньої системи задля iї розпізнавання у європейському просторі;

- можливості розбудови інноваційної моделі вищої фармацевтичної освіти, яка була б здатна не тільки адекватно реагувати на виклики часу, а й працювати на перспективу;

- прийняття зручної та зрозумілої градації дипломів, ступенів і кваліфікацій, використання єдиної системи кредитних одиниць (ECTS), що розширює можливості випускників Національного фармацевтичного університету самореалізуватися в професійній галузі в будьякій з європейських країн;

- сприяння студентському самовиявленню, що забезпечується - мобільністю, привабливістю, працевлаштуванням;
- конкурентоспроможність фахівця фармацевтичної галузі на ринку праці може забезпечити висока якість здобутої освіти, постійне самовдосконалення i навчання протягом усього життя;

- тісна взаємодія навчального процесу та фармацевтичної науки, необхідність залучення талановитої студентської молоді до науково-дослідної діяльності, формування наукового потенціалу.

3 метою реалізації зазначених нових орієнтирів у справі реформування фармацевтичної освіти є створення якісних стандартів, які б відповідали потребам часу та суспільства.

Вивчення документів міжнародних семінарів і матеріалів проекту “Налаштування освітніх структур в Європі” (Tuning Educational Structures in Europe TUNING) свідчить про пошуки методологічних засад проектування освітніх стандартів для європейського простору вищої освіти. Експерти визначають пріоритетними такі принципи:

1) орієнтацію на результати навчання;

2) поширення соціального партнерства освіти зі сферою праці [1].

Розрізнюють стандарт змісту навчання та стандарт навчальних досягнень. Європейські дослідники [2] характеризують зміст стандарту освіти як визначення бажаного рівня успішності та оволодіння змістом навчання - знаннями і навичками, які мають опанувати студенти вищого навчального закладу. Стандарт змісту навчання визначає ту частину навчальної програми, якою повинні оволодіти всі студенти. Стандарт навчальних досягнень визначає,

() В. П. Черних, І. С. Гриценко, С. В. Огарь, Л. М. Віннік 
наскільки добре ті, хто навчаються, оволоділи відповідною частиною змісту програм.

Система стандартів вищої освіти України включає i стандарти досягнень (галузевий компонент), і стандарти змісту навчання (компонент ВНЗ). Одне з призначень галузевих стандартів вищої фармацевтичної освіти - описати в термінах професійних здібностей, умінь та навичок випускників у контексті їхньої професійної діяльності. Згідно з принципами особистісного підходу, сформована професійна компетентність забезпечує якісне виконання професійної діяльності. Важливою складовою галузевих стандартів є засоби діагностики якості вищої фармацевтичної освіти. Їх функція - визначення вимог щодо кількісного та якісного оцінювання ступеня досягнення студентами (випускниками) цілей та змісту вищої професійної освіти.

“Чутливість" освітніх стандартів вищої фармацевтичної освіти до вимог роботодавців забезпечується використанням при їх розробці нормативних документів сфери праці-Національного класифікатора професій, Національного класифікатора видів економічної діяльності, кваліфікаційних характеристик працівників [3].

3 метою визначення тенденцій в питанні структури вищої фармацевтичної освіти були проаналізовані навчальні плани, затверджені МОЗ України.

У структурі типових навчальних планів ми проаналізували, як змінювалась структура підготовки про- візорів за циклами навчальних дисциплін (рис. 1).

За період з 2004 року дотепер у структурі вищої фармацевтичної освіти суттєво зменшилась питома вага гуманітарних та соціально-економічних дисциплін. Відсоток природничо-наукової підготовки поступово збільшувався, цикл професійних дисциплін змінювався не суттєво, а обсяг практики залишився без змін.

Спираючись на європейський досвід підготовки фахівців фармації та враховуючи потреби практичної фармації України, стає очевидним, що здійснення профілізації та спеціалізації у структурі підготовки провізорів необхідно розпочинати вже на перших курсах навчання. Залишається також не вирішеним питання щодо термінів підготовки магістрів фармації та визначення кваліфікацій у сфері фармацевтичної освіти.

Важливим при розробці нових стандартів є визначення змісту освітніх програм за активного діалогу зі сферою праці. Необхідно врахувати також змістовне наповнення вибіркової компоненти ВНЗ та студента - воно має відображати наскрізну систематизацію та структуризацію. Цикл нормативних дисциплін потребує скорочення їх кількості, а терміни навчальної та виробничої практичної підготовки необхідно переглянути і збільшити переддипломну до термінів, що діють у Свропі.

Таблиця 1. Зміни у змісті типових навчальних планів спеціальності “Фармація”

\begin{tabular}{|c|c|c|}
\hline Рік & № наказу МОЗ України & Внесені зміни \\
\hline 2004 & $\begin{array}{l}\text { № } 36 \text { від } 21.01 .2004 \text { р. "Про затвердження та } \\
\text { введення нового навчального плану підготовки } \\
\text { фахівців за спеціальністю “Фармація” }\end{array}$ & \\
\hline 2007 & $\begin{array}{l}\text { № } 446 \text { від } 01.08 .2007 \text { р. “Про внесення змін до } \\
\text { наказу МОЗ України № } 36 \text { від 21.01.2004 р.” }\end{array}$ & $\begin{array}{l}\text { Вилучено дисципліни блоку “Військова } \\
\text { підготовка” з переліку нормативних дисциплін. } \\
\text { Введені навчальні дисципліни “Екстремальна } \\
\text { медицина” та “Безпека життєдіяльності” }\end{array}$ \\
\hline 2009 & $\begin{array}{l}\text { № } 930 \text { від 07.12.2009 р. “Про затвердження } \\
\text { нового навчального плану підготовки фахівців } \\
\text { освітньо-кваліфікаційного рівня “спеціаліст” } \\
\text { кваліфікації “провізор” у вищих навчальних } \\
\text { закладах IV рівня акредитації за спеціальністю } \\
\text { “Фармація” }\end{array}$ & $\begin{array}{l}\text { Внесення змін до вивчення гуманітарних } \\
\text { дисциплін відповідно до вимог наказу МОН } \\
\text { України № } 642 \text { від 09.07.2009 р. } \\
\text { Введення державного іспиту з дисципліни } \\
\text { “Українська мова (за професійним } \\
\text { спрямуванням). } \\
\text { Введена дисципліна “Основи біоетики та } \\
\text { біобезпеки” }\end{array}$ \\
\hline 2010 & $\begin{array}{l}\text { № } 542 \text { від } 08.07 .2010 \text { р. “Про внесення змін до } \\
\text { навчального плану підготовки фахівців } \\
\text { освітньо-кваліфікаційного рівня “спеціаліст” } \\
\text { кваліфікації “провізор” у вищих навчальних } \\
\text { закладах IV рівня акредитації за спеціальністю } \\
\text { “Фармація”, затвердженого наказом МОЗ від } \\
\text { 07.12.2009 р. № 930” }\end{array}$ & $\begin{array}{l}\text { Внесені зміни на виконання наказу МОН України } \\
\text { від 29.03.2010 р. № 259, від 21.10.2010 р. № } \\
\text { 969/922/216. } \\
\text { Введена кредитно-модульна система організації } \\
\text { навчального процесу. } \\
\text { Вилучено державний іспит з дисципліни } \\
\text { “Українська мова (за професійним } \\
\text { спрямуванням) }\end{array}$ \\
\hline
\end{tabular}



системи організації навчального процесу у ВМ(Ф)НЗ III-IV рівнів акредитації”

Puc. 1. Розподіл дисциплін навчальних планів за циклами підготовки.

Висновок. Накопичений провідними фахівцями університету та фармацевтичних факультетів - розробниками освітніх стандартів позитивний досвід необхідно
49

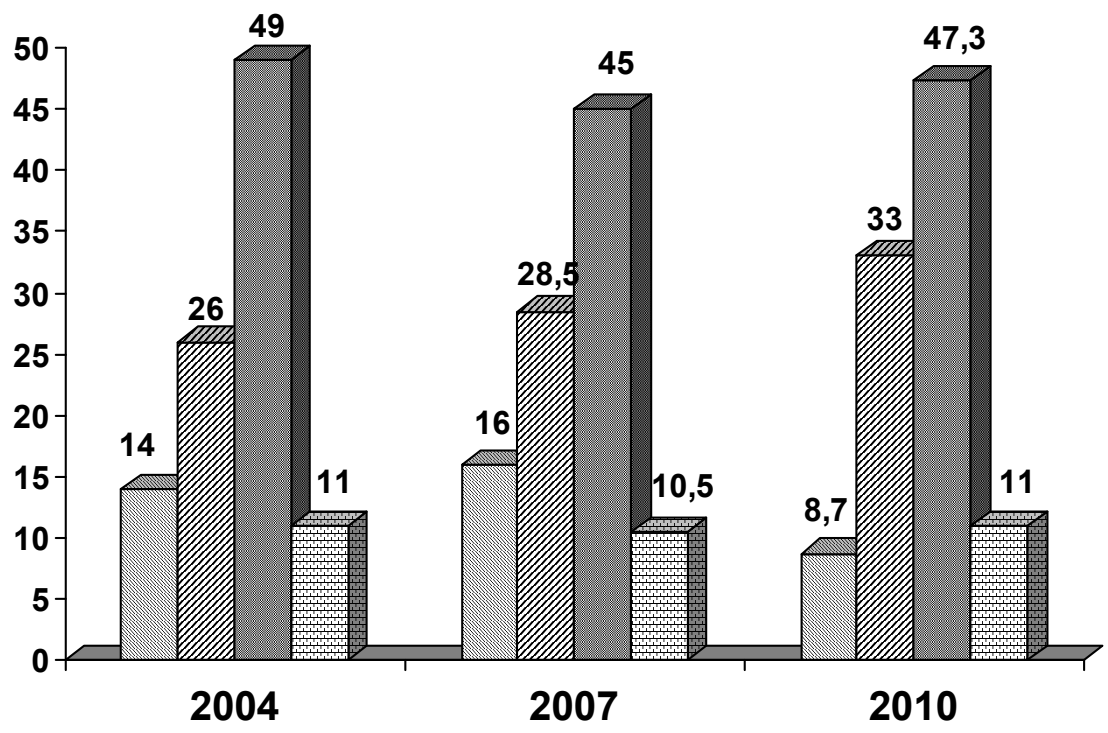

$\square$ гуманітарна та соціально-економічна

囚 природничо-наукова

$\square$ професійна

婳 практика

розвивати та удосконалювати при розробці стандартів нового покоління, враховуючи недоліки попереднього та опрацьований стан фармацевтичної освіти в Свропі.

\section{Лiтература}

1. UK Bologna Seminar: Using Learning Outcomes. Ediburg, 1-2 July 2004 //www.bologna-bergen2005.no; Tuning Education Structures in Europe // tuning.unideusto.org/ tuningeu.

2. UK Bologna Seminar: Using Learning Outcomes. -

Ediburg, 1-2 July 2004 // www.bologna-bergen2005.no;

3. Петренко В. А. Комплекс нормативних документів для розроблення складових системи стандартів вищої освіти / В. А. Петренко // Вища освіта. - 2003. - № 10. - 82 с. 